SARAH LIGHT, UC Cooperative Extension Agronomy Advisor in Sutter and Yuba counties BRAD HANSON, UC Cooperative Extension Weed Specialist at UC Davis

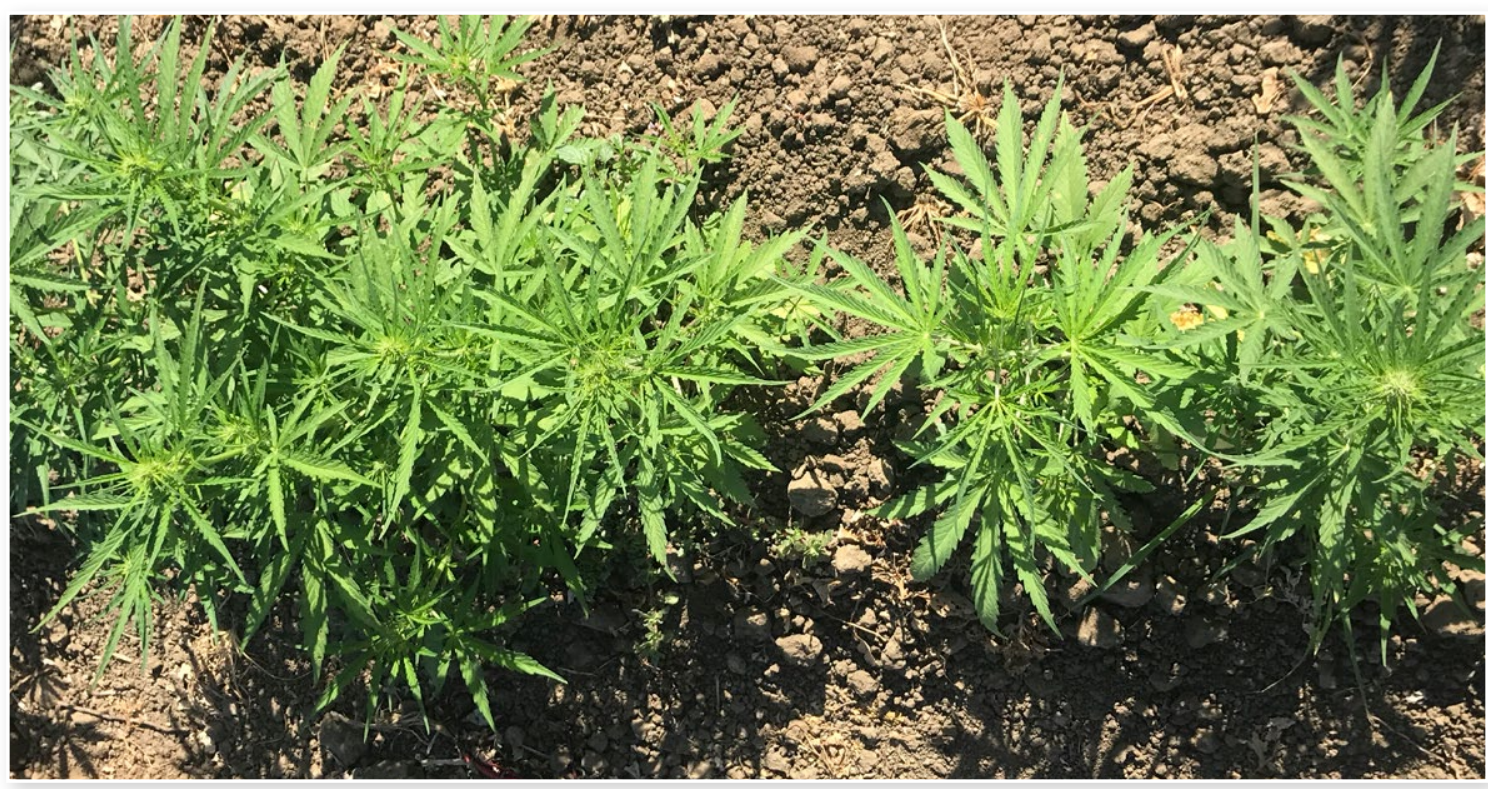

Healthy hemp plants.

\title{
Herbicide Symptoms on Hemp
}

T he introduction of a new crop into a landscape involves certain unknowns, including the risk of pesticide and herbicide drift from neighboring crops. Hemp (Cannabis sativa spp.) is a new, high-value commodity that is now being produced in many parts of California.

In this research-in order to begin an assessment of potential phytotoxicity issues that could occur when hemp is grown in diversified field-crop situations-plants were sprayed with herbicides that are widely used in a range of crops during the summer hemp growing season (May through September) in California's Central Valley. The herbicides selected could be sprayed on commodities planted adjacent to a hemp field. This UC Cooperative Extension publication provides a brief description of symptoms that could be expected from exposure to specific herbicides, or to those with similar modes of action, but does not address hemp's relative sensitivity to the full range of potential levels of exposure. (For useful background on herbicide injury symptoms, visit the "Herbicide Symptoms" website of the UC Statewide Integrated Pest Management website, herbicidesymptoms.ipm. ucanr.edu/.)

\section{METHODS}

Hemp plants were transplanted on July 25, 2019 in two rows onto 60 -inch beds. Three weeks later, on August 15, low-rate treatments were applied. Herbicide rates for this symptomology demonstration were based on $25 \%$ of common label rates in Central Valley agricultural systems (table 1). Treatments were applied to the foliage of plants, 12 to 18 inches tall, using a two-nozzle boom setup with one nozzle calibrated for 20 gallons per acre and the other 40 gallons per acre. Thus, one row of plants 
Table 1. Herbicides applied to hemp in a simulated drift symptomology demonstration in 2019

\begin{tabular}{|c|c|c|}
\hline Active ingredient* & Example trade name & Common registered uses in California \\
\hline Glyphosate & Roundup (among many products) & many agricultural, industrial, and homeowner uses \\
\hline Paraquat & Gramoxone, Parazone & preplant burndown in annual crops, orchard, vineyards \\
\hline Glufosinate & Rely, Lifeline, Finale & $\begin{array}{l}\text { preplant burndown in annual crops, orchards, vineyards; in-crop use in } \\
\text { Liberty-Link cultivars }\end{array}$ \\
\hline Saflufenacil & Treevix, Sharpen & orchards, alfalfa, corn, grasses \\
\hline Carfentrazone & Shark, QuickSilver & orchards and vineyards, cereal crops, some turf products \\
\hline Oxyfluorfen & Goal, GoalTender, Galigan & widely used in orchards, vegetable crops, fallow, roadsides, industrial sites \\
\hline Propanil & Stam, SuperWham & rice cropping systems \\
\hline Bispyribac-sodium & Regiment, Velocity & rice cropping systems, some turf products \\
\hline Imazapyr & Polaris, Habitat & industrial and roadsides, aquatic weeds, riparian and range restoration \\
\hline Rimsulfuron & Matrix, Grapple, Solida & corn, orchards and vineyards, tomatoes, noncrop and industrial sites \\
\hline Triclopyr & Garlon, Grandstand, Turflon & rice, brush and tree control, rights of way, aquatic weeds, turf products \\
\hline 2,4-D & 2,4-D (among many products) & broadleaf weed control in many grass and cereal crops \\
\hline Clopyralid & Transline, Confront & rangelands, roadsides, cereals, some tolerant crops \\
\hline Mesotrione & Broadworks, Callisto & orchards, corn, some legume crops \\
\hline Clomazone & Serano, Command & rice systems, some vegetable and berry crops \\
\hline Ammonium nananoate & Axxe & many preplant or directed-spray applications; organic-certified \\
\hline Methylated seed oil & $\begin{array}{l}\text { methylated seed oil (among many } \\
\text { products) }\end{array}$ & spray adjuvant used with many pesticides \\
\hline Sethoxydim & Fusilade & $\begin{array}{l}\text { grass weed control in many broadleaf crops and ornamentals; some } \\
\text { homeowner products }\end{array}$ \\
\hline Cyhalofop & Clincher & grass weed control in rice cropping systems \\
\hline
\end{tabular}

* Herbicide rates for this symptomology demonstration were based on $25 \%$ of common agricultural use rates and were glyphosate at 0.1 and 0.2 pounds of acid equivalent per acre (Ib ae/A); paraquat at 0.15 pounds of active ingredient per acre (Ib ai/A); glufosinate at $0.25 \mathrm{lb}$ ai $/ \mathrm{A}$; saflufenacil at $0.009 \mathrm{lb}$ ai/A; carfentrazone at $0.008 \mathrm{lb}$ ai/A; oxyfluorfen at $0.25 \mathrm{lb}$ ai/A; propanil at $1 \mathrm{lb}$ ai/A; bispyribac-sodium at $0.08 \mathrm{lb}$ ai/A; imazapyr at $0.15 \mathrm{lb}$ ai/A; rimsulfuron at $0.015 \mathrm{lb}$ ai/A; triclopyr at $0.15 \mathrm{lb}$ ai/A; $2,4-\mathrm{D}$ at $0.16 \mathrm{lb}$ ae/A; clopyralid at $0.02 \mathrm{lb}$ ai/A; mesotrione at $0.043 \mathrm{lb}$ ai/A; clomazone at $0.25 \mathrm{lb}$ ai/A; ammonium nanaoate at $10 \%$ volume per volume; methylated seed oil at $10 \%$ volume per volume; sethoxydim at $0.07 \mathrm{lb}$ ai/ $\mathrm{A}$; and cyhalofop at $0.07 \mathrm{lb}$ ai/A. Herbicides included appropriate surfactants at full rates if recommended on the product label.

was sprayed with approximately $25 \%$ of the labeled rate and the other with $50 \%$ of the labeled rate, but also at greater coverage. These rates and spray coverages are significantly higher than would commonly occur in herbicide drift situations-but the purpose of this demonstration was to compare typical symptoms from several common herbicide modes of action on this crop. Specific herbicide symptoms, progression over time, ultimate severity, and potential for recovery all can vary with route of exposure, spray coverage, droplet concentration, plant health, and environmental conditions. Thus, in a more typical drift situation, symptoms may be less dramatic than those documented in this publication, while direct applications of full rates may cause even more severe symptoms (including plant death).

Plants were photographed over a 2-week period $(1,2,4,7,12$, and 14 days after application) and photos were selected for inclusion based on their ability to illustrate typical herbicide damage. Photos are intended not to show symptom development over time but rather to show distinct symptoms for each herbicide. The date of each photograph is indicated in the figure captions as number of days after application. 


\section{HERBICIDES INCLUDED}

\section{Glyphosate}

Glyphosate is a postemergence herbicide that affects an enzyme important to the production of several specific essential amino acids in plants. Injury from drift of this type of herbicide typically is seen in the meristematic regions and youngest tissues first because these regions are rapidly growing and have the greatest need for amino acids. Glyphosate can translocate, or move within the plant, and moves from treated tissue to above- and belowground meristems (growing points). The most typical symptom, which was observed in hemp in this research, includes chlorosis (yellowing) in
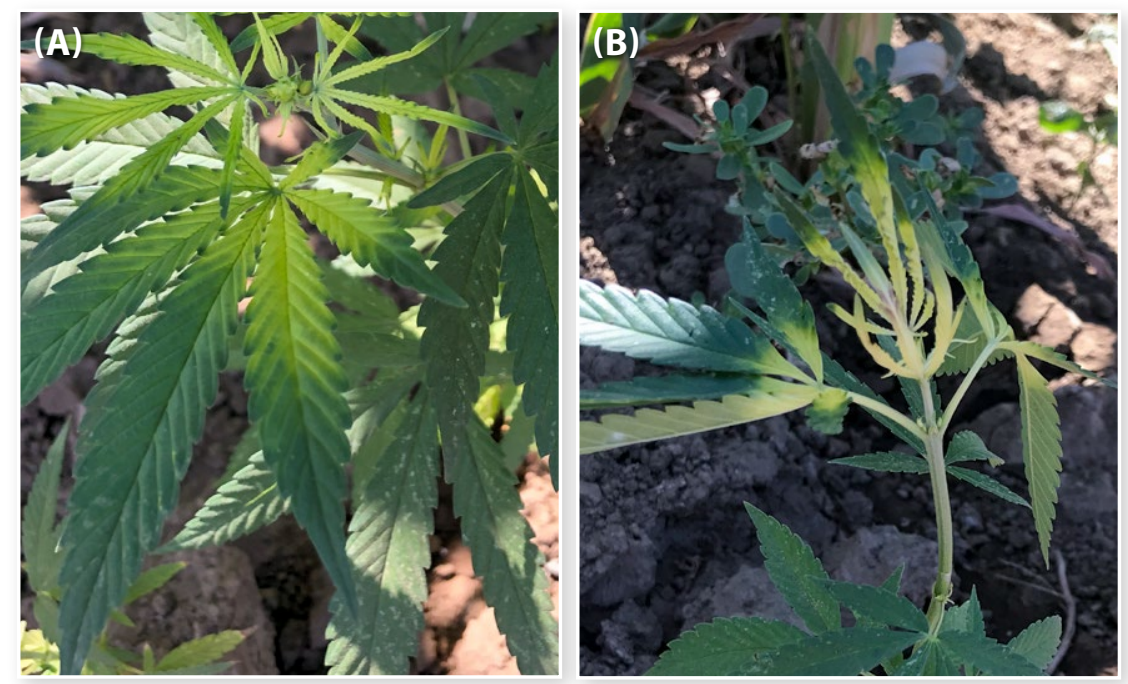

Figure 1. Glyphosate symptoms on hemp, 4 days after application (A) and 7 days after application (B).
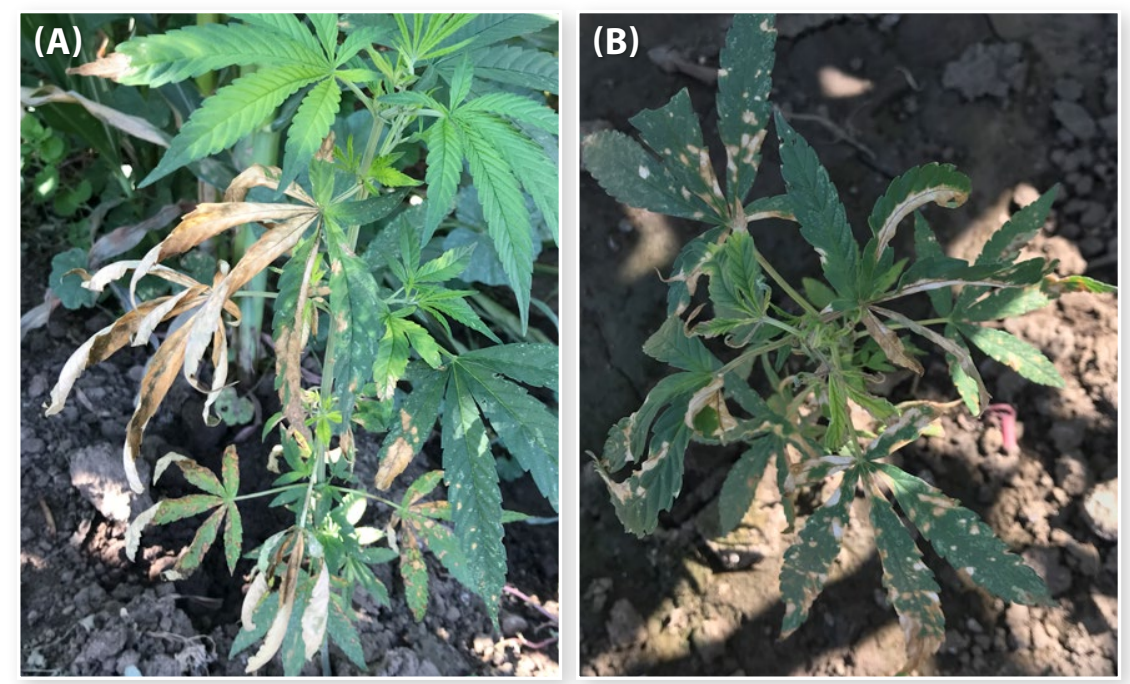

Figure 2. Paraquat symptoms on hemp, 4 days after application (A) and 7 days after application (B). younger leaves (fig. 1). Glyphosate injury can eventually lead to necrosis, beginning with the younger tissues and advancing to older leaves over the course of 5 to 10 days; some species can take on a purple coloration as well. In large annual plants or established perennial plants, sublethal doses can sometimes lead to witch's broom - a situation in which many shoots grow from one point on the stem, giving the appearance of a broom because the nodes between the shoots are very short. Sublethal doses can also lead to stacked leaves as the plant begins to regrow (that is, leaves appear to be growing on top of each other). Because the herbicide is tightly bound to soil, crop injury from glyphosate is almost always associated with foliar exposure.

\section{Paraquat}

Paraquat is a postemergence contact herbicide that disrupts energy flow during photosynthesis. The herbicide can act very rapidly (in a matter of hours), particularly under high-light conditions. Injury is due to membrane disruption by reactive oxygen and other free radicals; this results in leakage of cellular contents and rapid desiccation of affected tissues. Paraquat does not translocate well in plants, so symptom severity is often a function of coverage. Symptoms can range from chlorosis-yellowing of leaf tissue due to low chlorophyll-to chlorotic (yellow) or necrotic (dead) spots associated with individual spray droplets to full necrosis from complete spray coverage (fig. 2). If the dose is insufficient to kill the plant, new growth will not be damaged. Paraquat is extremely tightly bound to soil and is not likely to be taken up by plants via soil routes.

\section{Glufosinate}

Glufosinate inhibits glutamine amino acid synthesis and leads to the accumulation of toxic levels of ammonia within plant cells. Glufosinate movement in plants is fairly limited, so injury severity is often a function of concentration and coverage. Typical symptoms appear within a few days, beginning with wilting and chlorosis and progressing to necrotic tissue (fig. 3). Glufosinate injury is usually due to foliar exposure rather than exposure through soil routes. 


\section{PPO-inhibiting herbicides}

PPO-inhibiting herbicides-saflufenacil, carfentrazone, and oxyfluorfen-inhibit an enzyme important in chlorophyll synthesis, among other things. These herbicides can quickly lead to the formation of free radicals within cells, which can damage lipids and proteins and cause disruption of membranes. Cells and tissues quickly desiccate and dry out. Drift symptoms include chlorosis, usually followed by necrosis, at the point of contact (fig. 4). Some PPO herbicides are primarily used as foliar herbicides, while others can have both foliar and soil activity. Transport within the plant is somewhat limited and occurs via the
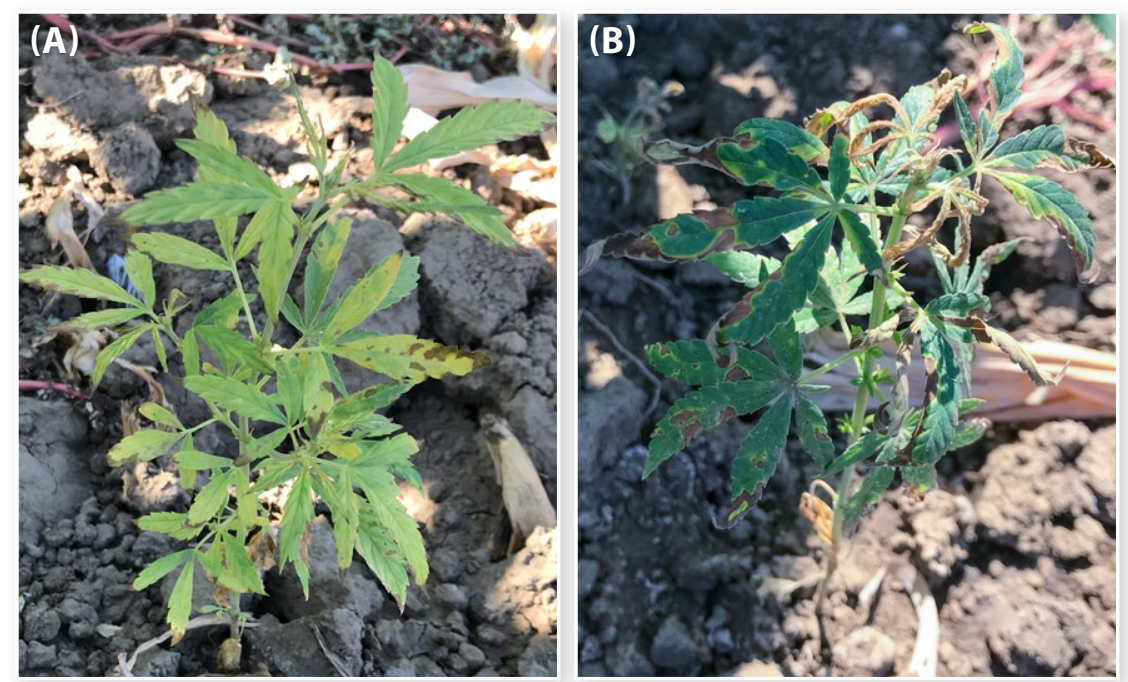

Figure 3. Glufosinate symptoms on hemp, 4 days after application (A) and 7 days after application (B).
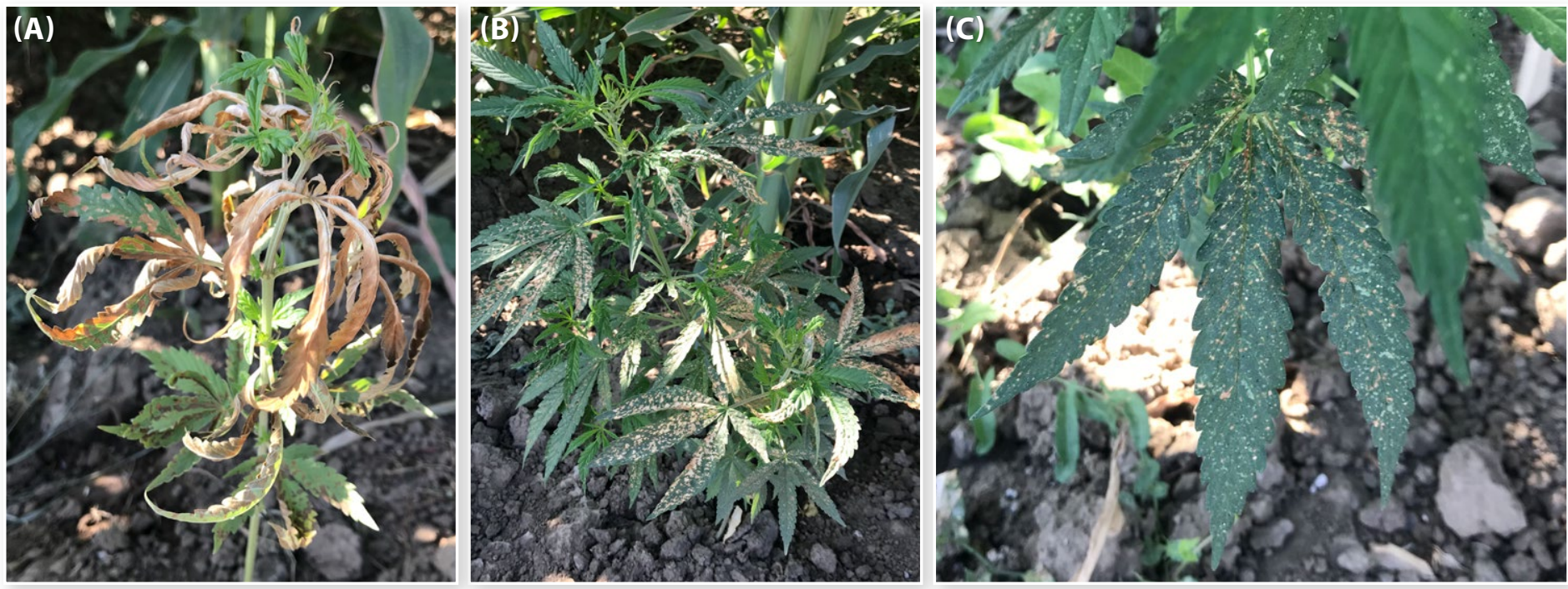

Figure 4. PPO-inhibiting herbicide symptoms on hemp, including saflufenacil 4 days after application (A); carfentrazone 4 days after application (B); and oxyfluorfen 14 days after application (C). xylem (water-conducting vessels). Because of this, symptom severity from PPO-inhibitor drift is a function of coverage, with low doses causing less dramatic and slower-developing symptoms, compared to those caused by greater exposure. However, if the dose is sublethal, new tissues that develop after foliar exposure usually are not affected.

\section{Propanil}

Propanil is a contact herbicide that inhibits photosynthesis by blocking electron transport through photosystem II. Propanil is translocated via the xylem. Thus, injury is usually first observed on the older, fully formed leaves because they photosynthesize more actively than younger, still-forming leaves. Often, injury is initially noted at the leaf margins (chlorosis leading to necrosis). Later, it moves further into the interveinal areas of the leaf (fig. 5). If the plant survives foliar exposure, newly formed leaves may not be affected. Although propanil in this example is primarily used as a foliar herbicide, some other photosystem II-inhibiting herbicides, such as simazine, atrazine, and diuron, are used as soil-applied materials, and symptoms can vary somewhat depending on route and amount of exposure.

\section{ALS inhibitors}

Several classes of herbicides, known as ALS inhibitors, inhibit the ALS enzyme, which is important in the synthesis of branched chain 

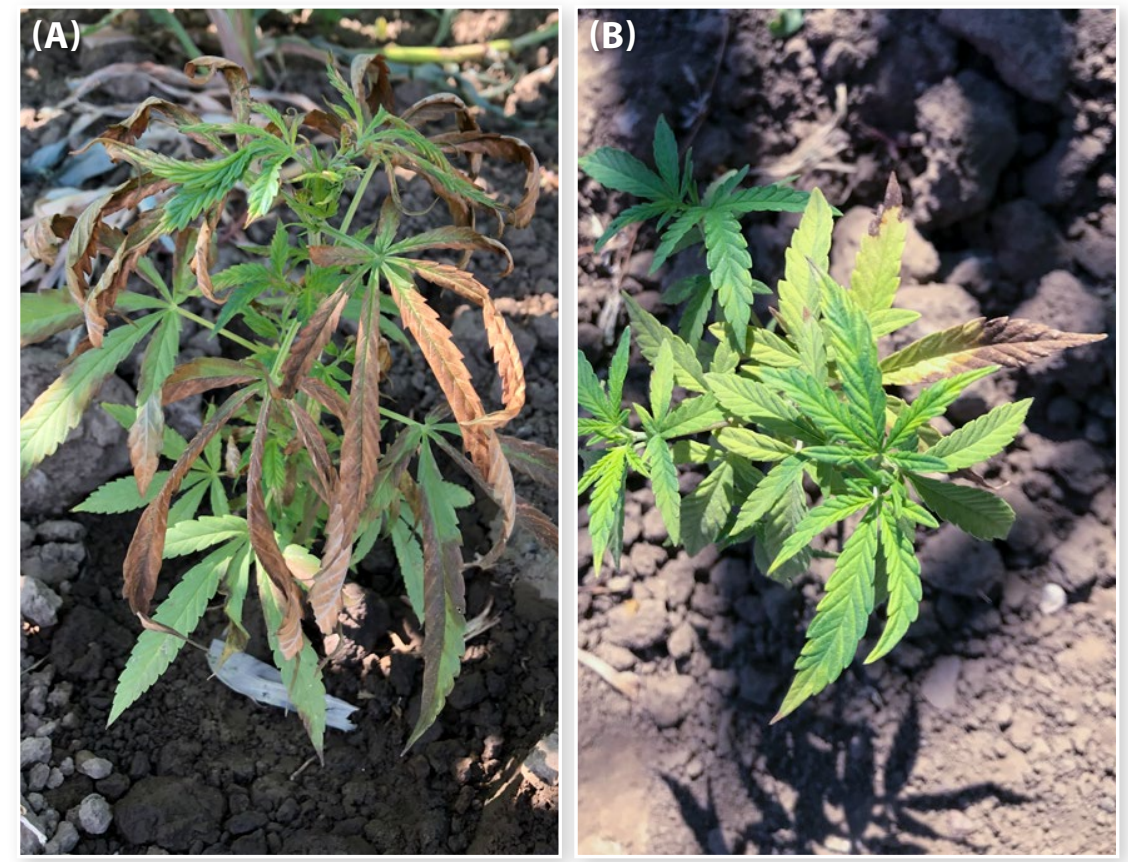

Figure 5. Propanil symptoms on hemp, 4 days after application (A) and 4 days after application (B). This photo pair demonstrates that symptoms can vary.
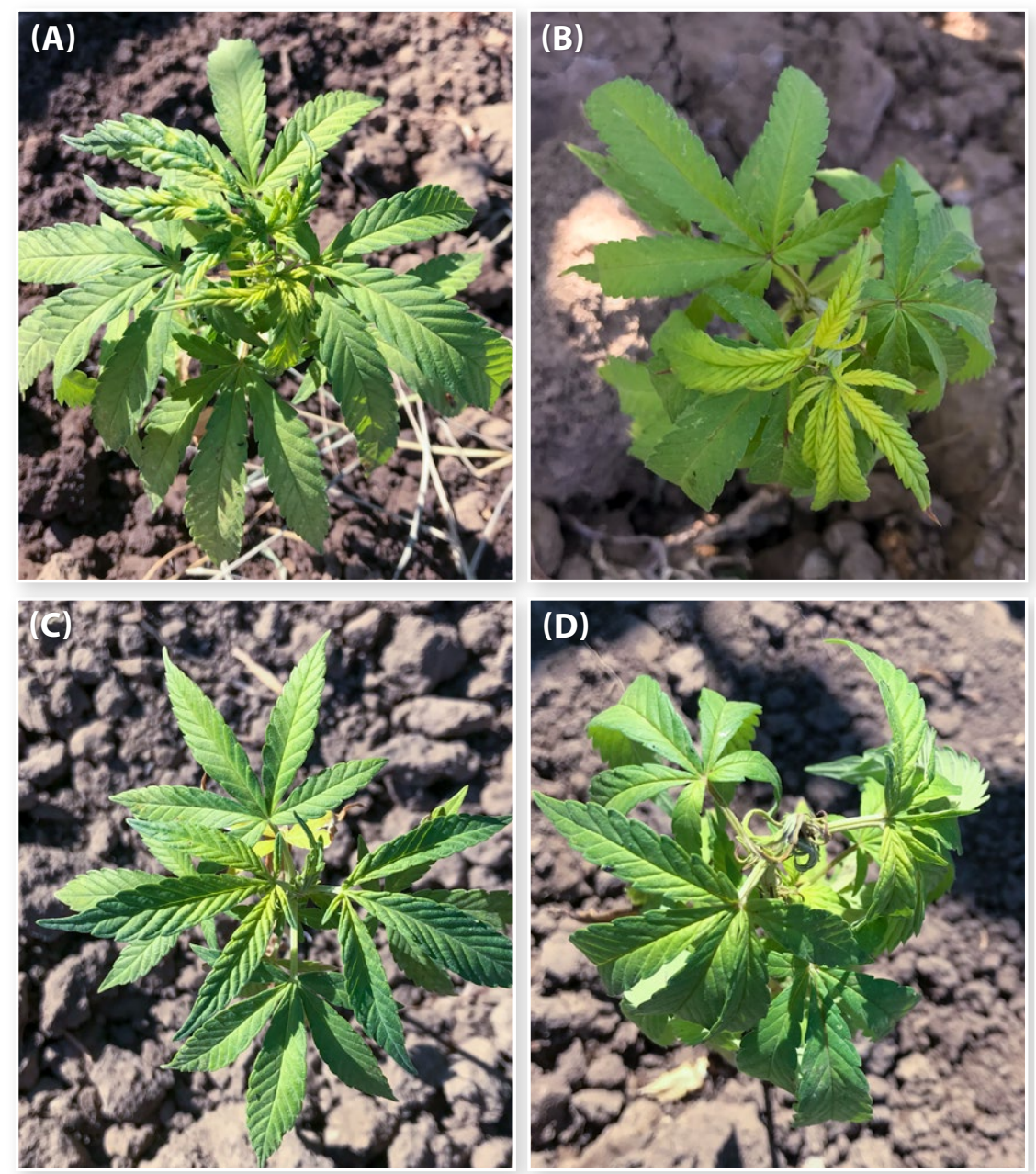

amino acids. Most of these herbicides-which include bispyribac-sodium, imazapyr, and rimsulfuron-have both foliar and soil activity. Like other herbicides that inhibit amino acid synthesis, symptoms from ALS inhibitors are usually first seen in the meristems and youngest tissues because they are rapidly growing and require large amounts of amino acids. At the whole-plant level, symptoms are typically characterized by general chlorosis leading to necrosis (fig. 6). Depending on the dose, sometimes an aboveground growing point may die and axillary meristems may be released from dormancy, which can result in an abnormal branching structure, as well as leaf stacking (see fig. 6A) and crinkling and stunting of leaves (see fig. 6D).

\section{Synthetic auxins}

Several classes of herbicides are known as synthetic auxins, plant growth-regulator herbicides, or auxin-mimics-including triclopyr, 2,4-D, and clopyralid. These foliar-applied herbicides affect primarily broadleaf plants, although some grasses are affected by some herbicides. In general, as hormone mimics, synthetic auxin herbicides affect many cellular processes and lead to abnormal cell division and cell growth. At the whole-plant level, this abnormal growth can take the form of leaf and stem twisting, cupping, bending, cracking, and other epinastic growth (fig. 7). In some cases, leaf thickening, strap leaves, and other abnormal growth are observed. These symptoms can

Figure 6. ALS-inhibitor symptoms on hemp, including bispyribac-sodium 4 days after application (A) and 7 days after application (B); imazapyr 4 days after application (C) and 7 days after application (D); and rimsulfuron 14 days after application (E). 
start relatively quickly after exposure and progress over days or weeks and eventually lead to necrotic tissues. Most exposure to synthetic auxin herbicide is via foliar routes; however, several herbicides in this class can persist in soil and be taken up by that route.

\section{HPPD-inhibiting herbicides and PDS- inhibiting herbicides}

HPPD-inhibiting herbicides (such as mesotrione) and PDS-inhibiting herbicides (such as
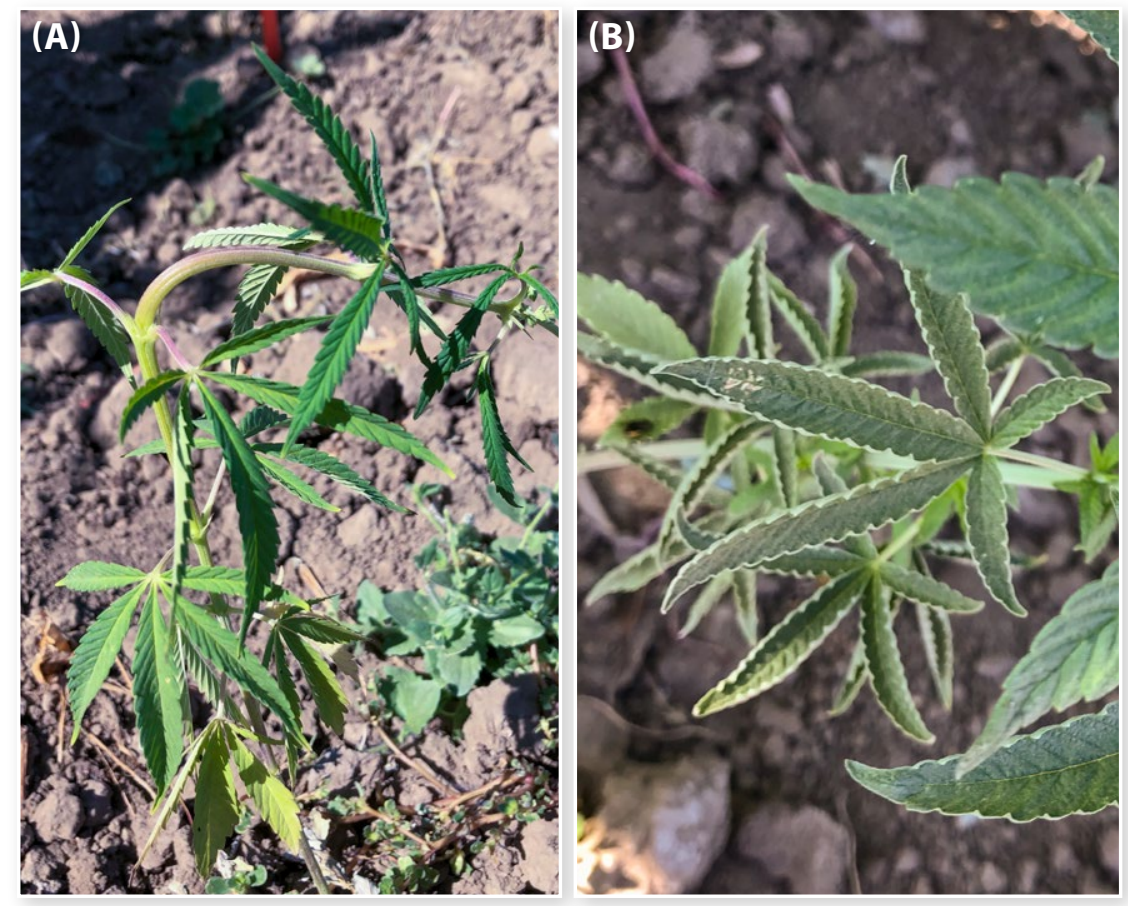

Figure 7. Synthetic auxin symptoms on hemp, including triclopyr 4 days after application (A) and 2,4-D 4 days after application (B).
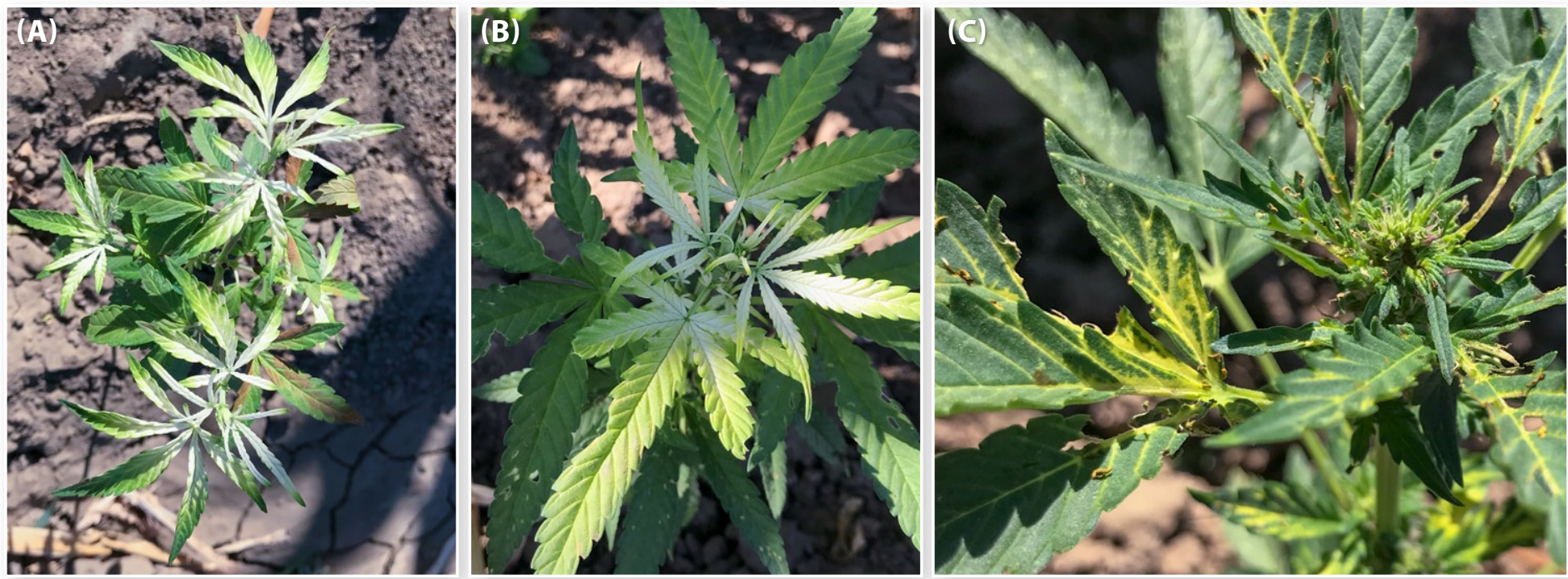

Figure 8. HPPD and PDS-inhibiting symptoms on hemp, including mesotrione 4 days after application (A), 4 days after application (B), and clomazone 7 days after application (C). Figures $8 \mathrm{~A}$ and $8 \mathrm{~B}$ demonstrate that symptoms can vary. clomazone) affect different steps in carotenoid biosynthesis. The carotenoids function to protect chlorophyll from damage caused by excess inhibited, the most common symptom is bleaching, which can range from yellow leaf tissue in some plants to almost pure white in others (fig. 8). Usually, symptoms are first observed in the newly formed tissues that were never able to produce carotenoids-but eventually they can progress to older tissues as existing carotenoids turn over and cannot be replaced. Bleaching can lead to tissue necrosis. Damage to established plants from drift of bleaching herbicides can be visually dramatic but rarely lethal. Damage to seedlings or young transplants from soil carry-over may be more damaging.

\section{Organic membrane-disrupting herbicides (ammonium nananoate)}

Most organic herbicides, such as ammonium nananoate, exhibit contact herbicidal activity. They disrupt cell membranes, which leads to cell and tissue desiccation (fig. 9). Like synthetic herbicides that disrupt membranes, these organic herbicides do not translocate well in plants, so symptom severity is often a function of coverage, and can range from specks caused by individual droplets to full necrosis in the case of complete coverage. If dose and coverage are sublethal, new tissues usually are not affected. light energy. When carotenoid synthesis is 


\section{Methylated seed oil}

Although methylated seed oil is not used alone for weed control, it was included in this demonstration (at 10\% volume per volume) because oil-based surfactants, or formulation emulsifiers in other pesticides, can sometimes

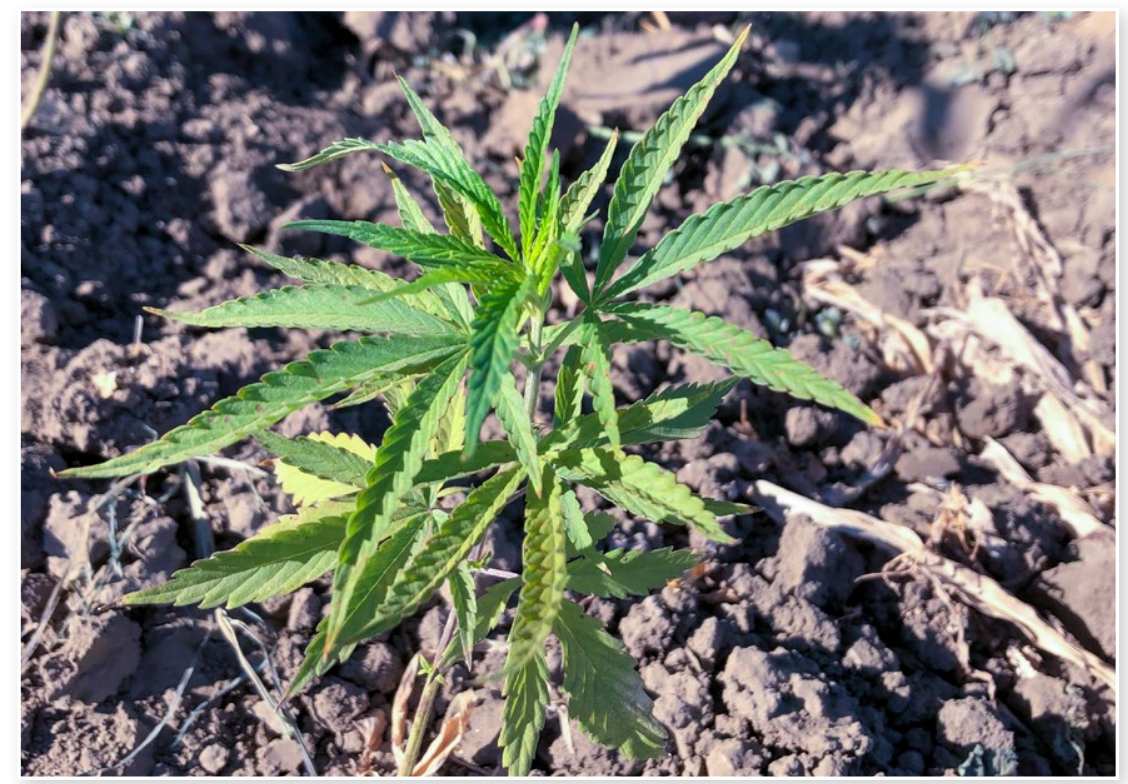

cause burning similar to that caused by contact herbicides. Like contact herbicides, these types of oils can solubilize membranes and lead to cell and tissue necrosis (fig. 10). Often this injury is limited to sprayed tissue, or even portions of leaves where droplets accumulate, increasing the effective localized dose. Symptoms from this kind of phytotoxicity typically are transient, and later-forming tissues are not directly affected. It is rare to observe these symptoms from drift from a surfactant in a tank mix, so in-field drift symptoms will likely not be as severe.

\section{ACCase-inhibiting herbicides (sethoxydim and cyhalofop)}

ACCase-inhibiting herbicides (sethoxydim and cyhalofop) inhibit a specific form of an enzyme common in grass plants but present in a slightly different form in broadleaf plants. Significant injury from ACCase herbicides is uncommon in broadleaf plants, although burn from the oil emulsifiers used in solution with these herbicides can occur. No symptoms were observed on hemp in this demonstration.

Figure 9. Ammonium nananoate symptoms on hemp, 1 day after application.
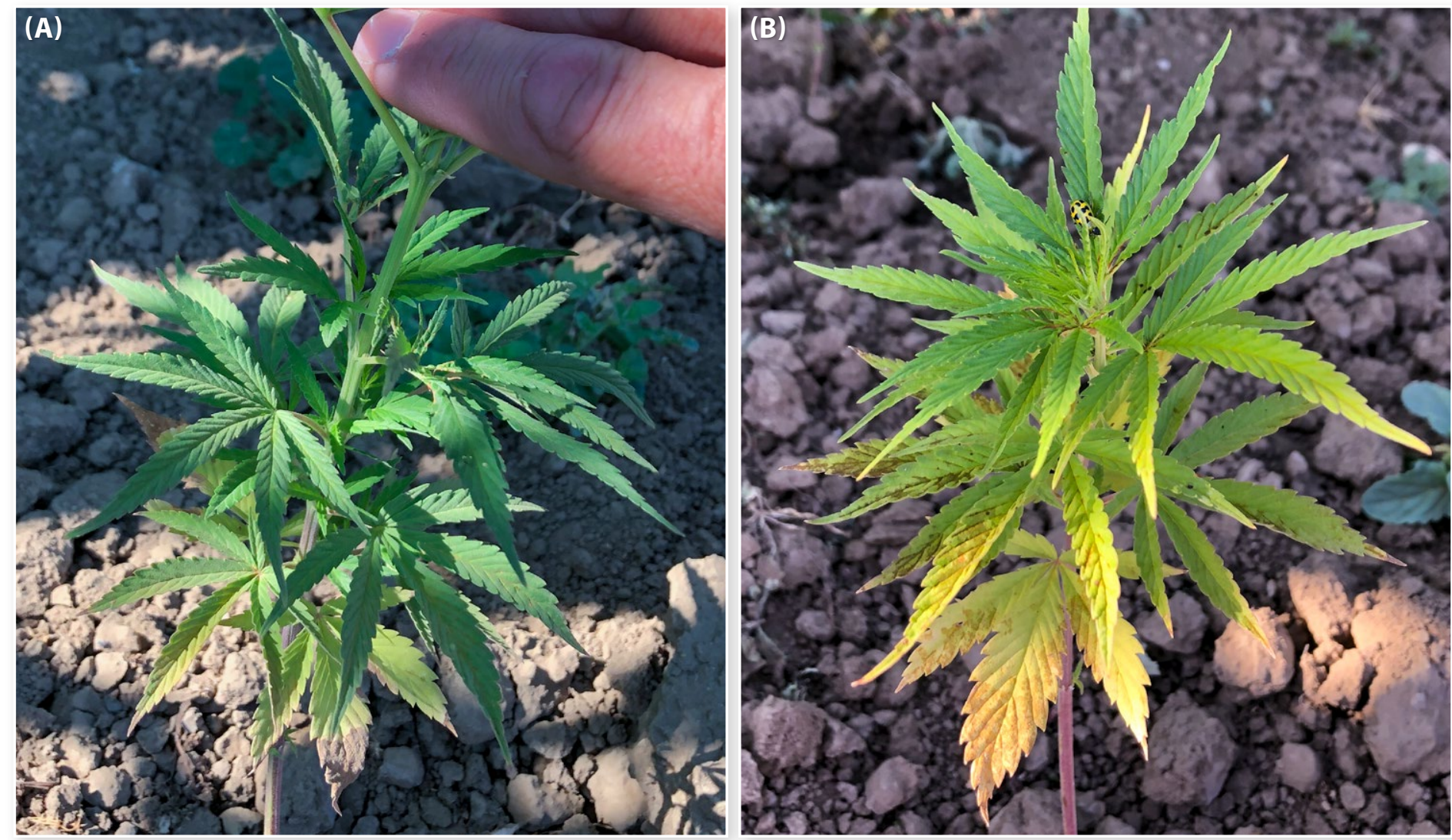

Figure 10. Methylated seed oil symptoms on hemp, 1 day after application (A) and 12 days after application (B). 
To order or obtain UC ANR publications and other products, visit the UC ANR online catalog at https://anrcatalog.ucanr. edu/ or phone 1-800-994-8849. Direct inquiries to

UC Agriculture and Natural Resources

Publishing

2801 Second Street

Davis, CA 95618

Telephone 1-800-994-8849

E-mail: anrcatalog@ucanr.edu

(C2021 The Regents of the University of California. This work is licensed under the Creative Commons AttributionNonCommercial-NoDerivatives 4.0 International License. To view a copy of this license, visit https://creativecommons.org/ licenses/by-nc-nd/4.0/ or send a letter to Creative Commons, PO Box 1866, Mountain View, CA 94042, USA.

Publication 8689

ISBN-13: 978-1-62711-184-3

The University of California, Division of Agriculture and Natural Resources (UC ANR) prohibits discrimination against or harassment of any person in any of its programs or activities on the basis of race, color, national origin, religion, sex, gender gender expression, gender identity, pregnancy (which includes pregnancy, childbirth, and medical conditions related to pregnancy or childbirth), physical or mental disability, medical condition (cancer-related or genetic characteristics), genetic information (including family medical history), ancestry, marital status, age, sexual orientation, citizenship, status as a protected veteran or service in the uniformed services (as defined by the Uniformed Services Employment and Reemployment Rights Act of 1994 [USERRA]), as well as state military and naval service.

UC ANR policy prohibits retaliation against any employee or person in any of its programs or activities for bringing a complaint of discrimination or harassment. UC ANR policy also prohibits retaliation against a person who assists someone with a complaint of discrimination or harassment, or participates in any manner in an investigation or resolution of a complaint of discrimination or harassment. Retaliation includes threats, intimidation, reprisals, and/or adverse actions related to any of its programs or activities.

UC ANR is an Equal Opportunity/Affirmative Action Employer. All qualified applicants will receive consideration for employment and/or participation in any of its programs or activities without regard to race, color, religion, sex, national origin, disability, age or protected veteran status.

University policy is intended to be consistent with the provisions of applicable State and Federal laws.

Inquiries regarding the University's equal employment opportunity policies may be directed to: Affirmative Action Compliance and Title IX Officer, University of California, Agriculture and Natural Resources, 2801 Second Street, Davis, CA 95618, (530) 750-1343. Email: titleixdiscrimination@ ucanr.edu. Website: https://ucanr.edu/sites/anrstaff/Diversity/ Affirmative_Action/

To simplify information, trade names of products have been used. No endorsement of named or illustrated products is intended, nor is criticism implied of similar products that are not mentioned or illustrated.

An electronic copy of this publication can be found at the UC ANR catalog website, http://anrcatalog.ucanr.edu/.

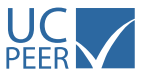

This publication has been anonymously peer reviewed for technical accuracy by University REVIEWED of California scientists and other qualified professionals. This review process was managed by UC ANR Associate Editor for Vegetable Crops and Plant Pathology Brenna Aegerter.

web-5/21-LC/AK 